\title{
The actual controller of listed companies and innovation input- Evidence from A-share listed companies in China
}

\author{
Jiao-jiao $\mathrm{Wu}^{1}$, Wei-dong $\mathrm{Su}^{2}$ \\ ${ }^{1}$ QILU University of Technology, Jinan, Shandong , 250353, China \\ ${ }^{2}$ QILU University of Technology, Jinan, Shandong, 250353, China
}

\begin{abstract}
Many scholars have researched the relationship between corporate governance and innovation input from different perspectives. This paper studies the innovation input effects from the angle of actual controllers of listed companies, using the data of China's A-share listed companies in 2007-2013. The results indicate the nature of the state-owned enterprises has no significant effect on innovation input of the enterprise; the higher the actual controllers' control is, the less conducive to enterprise innovation input; the two rights separation degree of actual controllers attaches no significant impact on innovation input of the enterprise.
\end{abstract}

Keywords: Actual controller, Innovation input, Panel data.

\section{Introduction}

Corporate governance has got more and more attention of the governments and has become a hot spot of academia since its birth in the 1970s. In the 1990s, however, the concentration has been found to be the dominant type for most countries in the structure of corporate ownership and control. In this case, only trace the company's ultimate property owners can we better understand the modern company ownership structure, control structure and the relationship with performance of corporate governance.

Large shareholders have played an increasing important role in corporate governance, according to the conduction mechanism of the ultimate property theory, the actual controller who actually masters the business decisions and financial policy of listed companies is the main body. Scholars have studied the actual controllers from different perspectives. For example, Kun Su (2013) has studied the influence of the actual controller, marketization process on capital structure, it is found that capital structure is associated with the degree of two rights separation of the actual controller and cash flow right is negatively related to the capital structure and debt financing has facilitated the actual controller's grab behavior. Lu-zhen Bai (2013) has test the influence of different nature of actual controller on the earning management before and after accounting standards reform,it is found that after the reform of accounting standards, the degree of earnings management of the central government-owned enterprises has not changed significantly, the degree of earnings management of local government-owned companies and private companies are significantly improved, and both the degree of earnings management do not significant differences. Xiang-yi Xu, Li-sheng Song(2009) have the important influence in the actual controller on the information disclosure of listed companies, it is found that the actual controllers' cash flow rights and control of listed companies and information disclosure transparency have significantly positive correlation.

This paper aims to study the influence of the actual controller on innovation input from the actual controllers' nature, the concentration of control and two rights separation degree, which is organized as follows: the second part is theoretical analysis, which analyzes the influence of the nature of the actual controllers, control degree and the two rights separation degree on innovation input; the third part uses the panel data of China's A-share listed companies from 2007 to 2013 to test the influence of the actual controller on innovation input; the fourth part is the conclusions and suggestions. 


\section{Theoretical analysis of the actual controller and innovation input}

\subsection{The nature of actual controllers and innovation input}

\subsubsection{Actual controllers and the nature}

The actual controller is not necessarily the shareholders, but can actually dominate company's operation through investment relations, agreements or other arrangements. The actual controller may be natural persons, legal persons or other organizations that can actual control the listed companies.

GTA CSMAR database classifies the actual controller into three types such as state-owned enterprises, private enterprises, non-enterprise units, natural person according to academic classification and existing data. Taking the purpose of this paper into account, we divide the nature of the actual controller of listed companies into state-owned and non-state categories, the actual controller of state-owned property, including state-owned enterprises and state-owned institutions.

2.1.2. The nature of actual controllers and innovation input

It is not inclined to innovation input for the actual controller of the state-owned property. The reason is that the management of state-owned holding companies, mostly coming from government officials, even itself has a certain level, despite there are incentive assessment indicators, the idea that the political field "seeking not accomplishment, but faults free" is more likely to affect their business decision whether to invest innovation or not, and compared with the actual controller of non-state, which is more inclined to take a conservative growth that is taking the existing way and abandon innovation, and even the management is willing to take an active management strategy, the introduction of innovative investment, but the drawbacks of a state-owned enterprise system hinder its implementation in a way. Therefore, we put forward the following assumptions:

H1: The nature of the actual controllers for state-owned company has no obvious effect on the innovation.

\subsection{The actual controller's control degree and innovation input}

For the actual controller of listed companies, the higher the control degree is, the more it has sufficient capacity and motivation to engage in corporate governance, thereby enhancing the role of internal governance of companies, which generally adopt and implement a proactive management strategy to promote the improvement of business performance.

If the actual controller has higher excess control degree, it would lack supervision and balance within the company, which easily leads to "large shareholders control", and along with the weak external governance is, the actual controller will be likely to erode corporate profits, deprive minority shareholders' interests, resulting in high agency costs and decreasing corporate performance. Meanwhile, the "predominant of one shareholder only one big share" results in a lack of democracy and scientificity, autocratic decision-making behavior in company's decision mechanism, which has a negative impact on innovation input, and The increase of equity degree of control of the actual controllers will widen the gap between the cash fluent and voting rights, and increase negative effect on innovation input. So, we put forward the following assumption:

$\mathrm{H} 2$ : The higher control degree of actual controller is, it would be unlikely to innovate input.

\subsection{Two rights separation of actual controllers and innovation input}

Actual controllers can adopt a variety of ways for the control of company, large shareholders through the pyramid shareholding structure, cross-shareholdings to achieve the separation of control and cash flow rights, thus actual controller getting more control with less cash flow investment. When control and cash flow right separating, the actual controller may use it to gain personal interests. The greater the separation of cash flow right and control of the actual controllers are, the greater the rate of the actual controllers for private interests is. Therefore, in this case, the actual controllers which have more control right can reduce investment in enterprise innovation and development, so we put forward the following hypothesis:

H3:The greater the two rights separation degree of the actual controller is, the more it is conducive to innovation input. 
3. The empirical test of the impact of actual controllers on the innovation input

\subsection{The empirical model and method}

\subsubsection{The selection of variables}

(1)Explained variable. In this paper, corporate R \& D is used to measure innovation input.

(2)Control variables. Business innovation input may be subject to company's size, profitability, the capital structure, and therefore we regard the total assets, return on assets, asset-liability ratio as control variables.

(3)Explanatory variables. This paper investigates the effect of the nature of the actual controller, control systems, two rights separation on innovation input. Explanatory variables will have three categories: the first variable is used to describe the dummy variables of the actual controller whether the state-owned or not; the second is used to describe control degree of actual controller of listed companies, respectively, using the cash flow rights ratio and control rights radio to measure; the third category is the separation of control rights and cash flow rights, both of which are measured by the difference of the ratio.

Definition and interpretation of all variables are presented in Table 1.

Table 1 definition and interpretation of variables

\begin{tabular}{|c|c|c|c|}
\hline Classification & Variable names & Symbol & Description \\
\hline Explained variable & $\begin{array}{l}\text { R \& D } \\
\text { expenditure }\end{array}$ & log_DE & On corporate $\mathrm{R} \& \mathrm{D}$ expenditure logarithmic \\
\hline \multirow{3}{*}{ Control variables } & Company Size & log_assets & Logarithm of total assets at the end \\
\hline & Capital Structure & alr & Asset-liability ratio \\
\hline & Profitability & roe & ROE ratio of net profit and shareholders' equity \\
\hline \multirow{4}{*}{$\begin{array}{l}\text { Explanatory } \\
\text { variables }\end{array}$} & \multirow{3}{*}{$\begin{array}{l}\text { The actual controllers' } \\
\text { control degree }\end{array}$} & conown & $\begin{array}{l}\text { Actual controllers of listed companies have } \\
\text { ownership proportion, the ratio of cash flow } \\
\text { rights }\end{array}$ \\
\hline & & concon & $\begin{array}{l}\text { Actual controllers of listed companies have } \\
\text { control proportion }\end{array}$ \\
\hline & & sper & Two rights separation \\
\hline & $\begin{array}{l}\text { The nature of actual } \\
\text { controllers }\end{array}$ & sodum & $\begin{array}{l}\text { Dummies, when the actual controllers are the } \\
\text { state-owned institutions or state-owned } \\
\text { enterprises, the value is } 1 \text {, otherwise the value is } 0\end{array}$ \\
\hline
\end{tabular}

\subsubsection{The sample and model}

This paper selects panel data of A-share listed companies from 2007 to 2013 in Shanghai and Shenzhen to conduct empirical test, the relevant data of the listed company's actual controller and control variables derived from GTA data service center.

This paper adopts the panel data of the listed companies that we can get in Shanghai and Shenzhen for the most recent years, so we consider the establishment of the panel data model, taking too much cross-sectional samples into account, we use the industry as a grouping variable, we use the China Securities Regulatory Commission (2001)to be the industry classification criteria ${ }^{6}$ in accordance with the research practice of The Securities Market, in addition to the manufacturing sector using two points to classify, and the rest have taken primary industries, so all listed companies are divided into 22 industries. Corresponding three types of panel data models are as follows:

$$
\begin{aligned}
{\log \_D E_{i, t}=}_{1} & \beta_{0}+\beta_{1} \log \_ \text {assets } \\
i, t & +\beta_{2} \text { roe }_{i, t}+\beta_{3} \text { alr }_{i, t} \\
& +\theta_{1} \text { sodum }_{i, t}+\theta_{2} \operatorname{HLD}_{i, t}+\lambda_{i, t}+\varepsilon_{i, t}
\end{aligned}
$$

$$
\begin{aligned}
\log \_\mathrm{DE}_{\mathrm{i}, \mathrm{t}}= & \beta_{0}+\alpha^{(\mathrm{j})}+\beta_{1} \log \_\operatorname{assets}_{\mathrm{i}, \mathrm{t}}+\beta_{2} \text { roe }_{\mathrm{i}, \mathrm{t}}+\beta_{3} \text { alr }_{\mathrm{i}, \mathrm{t}} \\
& +\theta_{1} \text { sodum }_{\mathrm{i}, \mathrm{t}}+\theta_{2} \mathrm{HLD}_{\mathrm{i}, \mathrm{t}}+\lambda_{\mathrm{i}, \mathrm{t}}+\varepsilon_{\mathrm{i}, \mathrm{t}}
\end{aligned}
$$

$$
\begin{aligned}
{\log \_D E_{i, t}=}_{=} & \beta_{0}+\mu^{(j)}+\beta_{1} \log \_\operatorname{assets}_{i, t}+\beta_{2} \text { roe }_{i, t}+\beta_{3} \operatorname{alr}_{i, t} \\
& +\theta_{1} \text { sodum }_{i, t}+\theta_{2} \operatorname{HLD}_{i, t}+\lambda_{i, t}+\varepsilon_{i, t}
\end{aligned}
$$

Definition and interpretation of the variables in the model are shown in Table 1. HLD is to describe the actual controller's variables - the control degree of the actual controller (respectively present in Table 1 
conown, concon), two rights separation (present in Table 1 sper variable); $\alpha^{(\mathrm{j})}$ of equation $(2)(\mathrm{j}=1,2, \ldots, 22)$ is a constant, being used to reflect fixed effects of the $\mathrm{j}$-th industry, $\mu^{(\mathrm{j})}$ of equation ( 3$)(\mathrm{j}=1,2, \ldots, 22)$ is normally distributed random variables, being used to reflect random effects of the $\mathrm{j}$-th industry; $\varepsilon_{\mathrm{i}, \mathrm{t}}$ represents the random error term.

With the utilization of the panel data model testing the effect of the actual controller on innovation input, we must firstly conduct model selection, namely, from the model (1) - (3) to select one, the method is selective testing between any two: F-test is used to select between mixed model and fixed effects model; using
LM test between mixed model and random effects model; using the Wald test between fixed effects model and random effects model.

\subsection{Estimation results and analysis}

Innovation input indicators are the explanatory variables, respectively, the nature of the actual controller, control degree and two rights separation, three control variables are regarded as dependent variables and used to conduct regression and selection of models, the results of selection are random effects models of the industry, the estimated results are shown in Table 2 .

Table 2 Effect analysis of actual controller on innovation input

\begin{tabular}{|c|c|c|c|}
\hline & Model1 & Model2 & Model3 \\
\hline \multirow[t]{2}{*}{ constant term } & $5.232 * * *$ & $5.209 * * *$ & $5.156^{* * *} *$ \\
\hline & $(7.26)$ & (7.24) & $(7.14)$ \\
\hline \multirow[t]{2}{*}{ sodum } & -0.16 & -0.173 & $-.229 *$ \\
\hline & $(-1.67)$ & $(-1.83)$ & $(-2.4)$ \\
\hline \multirow[t]{2}{*}{ concon } & & $-0.00843^{* *}$ & \\
\hline & & $(-3.21)$ & \\
\hline \multirow[t]{2}{*}{ conown } & $-0.00646^{* *}$ & & \\
\hline & $(-2.60)$ & & \\
\hline \multirow[t]{2}{*}{ sper } & & & -0.00479 \\
\hline & & & $(-0.92)$ \\
\hline \multirow[t]{2}{*}{ log_assets } & $0.544 * * *$ & $0.551 * * *$ & $0.536 * * *$ \\
\hline & $(14.27)$ & (14.4) & (14.08) \\
\hline \multirow[t]{2}{*}{ alr } & $-2.179 * * *$ & $-2.194 * * *$ & $-2.00 * * *$ \\
\hline & $(-7.08)$ & $(-7.17)$ & $(-6.61)$ \\
\hline \multirow[t]{2}{*}{ roe } & -0.377 & -0.3123 & -0.4259 \\
\hline & $(-0.52)$ & $(-0.43)$ & $(-0.59)$ \\
\hline R-sq: Within & 0.1068 & 0.1048 & 0.1041 \\
\hline Between & 0.12 & 0.132 & 0.111 \\
\hline overall & 0.0845 & 0.0865 & 0.083 \\
\hline$\chi^{2}$ statistics & $230.28 * * *$ & $234.27 * * *$ & $223.71 * * *$ \\
\hline
\end{tabular}

Note: Figures in brackets are the corresponding standard errors of estimated coefficients; *** represents at $0.1 \%$ significance level significantly, $* *$ represents at $1 \%$ significance level significantly, ${ }^{*}$ stands at $5 \%$ significance level significantly .

As can be seen from Table 2, the three models have higher goodness of fit, we can see from wald $\chi^{2}$ statistics that used to test the overall significance of the term, three equations in general are extremely significant.

Firstly, let us look at the impact of the nature of the actual controller on innovation input. For the enterprise of state-owned nature, the variable coefficients of the nature of the actual controller are estimated to be negative and not significant, the actual controller of listed companies in the case of state-owned enterprises is not conducive to innovation input, hypothesis $\mathrm{H} 1$ comes into existence.

Next is the impact of the actual controller's control degree on innovation input analysis. As can be seen from Table 2, the coefficient estimates of the proportion of control variables and the proportion of cash flow 
variables are significantly negative, the higher the control degree of the actual controller is, the less it is conducive to innovation input of companies, hypothesis $\mathrm{H} 2$ comes into existence.

Again, let us analyze the impact of two rights separation on innovation input. As can be seen from Table 2, the variable coefficient of two rights separation is estimated to be negative, but not significant. Hypothesis H3 can't come into existence.

Finally, it is the analysis of the impact of control variables on innovation input. We can see from the regression results of the control variables, the regression coefficient of company size variable log_aasets is significantly positive, the larger the company is, the more it is likely to promote innovation input, it is entirely reasonable, the larger the scale of enterprise is, the necessary financial resources and other conditions of innovation are also more likely to possess, with the expansion of business scale, enterprises have gradually entered a mature stage, and the high growth phase ends slowly, in order to maintain the level of development of enterprises, companies will introduce new technologies to promote innovation, thus enabling enterprises to maintain their vitality; the regression coefficient of asset-liability ratio alr is significant negative, the higher the debt ratio is, the less it is conducive to innovation, and the reason is that an increase in liabilities for the same company means fewer investment opportunities, thereby affecting the innovation input; the regression coefficient of the ratio of net profit and shareholders' equity roe is not significant.

\section{Conclusions and recommendations}

In this paper,we study the relationship between actual controller and innovation input from the perspective of theory and empiricism, the results show that: (1) the control degree of actual controller has a negative impact on innovation input; (2) the actual controller of the state-owned institution is not conducive to innovation input, and we also found: (3) the larger company size is, the more it is beneficial to innovation input, the higher the debt ratio is, the less it is conducive to innovation input. This study provide an important reference for the improvement of governance mechanisms that the actual controller of domestic listed companies.

\section{Acknowledgments}

This work has been funded by Humanities and Social Science Foundation of Ministry of Education of China (12YJA630102).

\section{References}

[1] Ting-qiu Cao, Hu-sheng Liu.N. Reference, "Major shareholder governance and corporate governance efficiency", "Reform”, p33-37, No.1, 2003.

[2]Hua-cheng Wang, Chun-ling Li, Chuang Lu.N. Reference, "A Case Study of the Impact of Controlling Shareholders on the Listed companies' Cash Dividend Policies", "Management World",p122-127, No. 1, 2007.

[3] Kun Su.N. Reference, "The Effect of Real Controller and Marketization Process on Capital Structure”, "Systems Engineering”, p18-28, No.1, 2013. [4] Lu-zhen Bai, N. Reference, “Accounting Standards Reform, the Nature of Actual Controller and Earnings management", "The Theory And Practice Of Finance And Economics", p47-51, No.181, 2013.

[5] Xiang-yi Xu, Li-sheng Song, N. Reference, "The Study on Ultimate Controlling Owner and Information Disclosure Transparensy of Listed Company", “Economics and Management”, p59-66,No.10,2009.

[6] The China Securities Regulatory Commission in 2012 issued a "Listed Company Industry Classification Guidelines (2012 Amendment)", but because the sample interval in this paper is from 2007 to 2013, in order to be consistent, and the new industry classification too small, some industries have small number of companies, so here is the use of a 2001 industry classification standards. 